\title{
THE FACTORS SUPPORTING THE SLOVAK TEACHERS' TURNOVER ACCORDING THE TYPE OF SCHOOL
}

\author{
Monika Magdová, Miroslava Bozogáňová, \& Marianna Berinšterová \\ Institute of Pedagogy and Psychology, Faculty of Humanities and Natural Science, \\ The University of Presov (Slovakia)
}

\begin{abstract}
When it comes to the teaching profession, Slovak teachers report a number of problematic issues that lead to many negative consequences in well-being, physical and mental health, and subsequently to considerable turnover rate. According the research studies, there are numerous factors related to teacher turnover, but we assume that turnover are closely linked to the situation in the country, economic conditions etc. Our aim was to find, which of research factors are important among Slovak teachers according the type of school, in which they teach. The research sample consisted of 132 teachers $(87.1 \%$ women), aged 24 to $68(\mathrm{M}=38.03, \mathrm{SD}=10.2)$. Of the total number of teachers, $15.6 \%$ worked at preschools, 53.9\% worked at primary schools, $13.3 \%$ worked at secondary vocational schools, $14.1 \%$ worked at secondary schools. An online questionnaire measuring: gender, age, and the type of school the individual teaches in. Subsequently, the teachers had a list of 27 areas at their disposal, where they were able to choose a maximum of 7 areas, they consider to be the most problematic and causing possible turnover in the teaching profession. Descriptive statistics were used for data analyses. In relation to the results, we interpreted as problematic these areas, which were marked at least one third of the respondents. We stated that teachers from different type of schools agreed on what is problematic in teacher profession and what can influence their turnover, except the teachers from preschools. Teachers from different type of schools ( $\mathrm{a}=$ primary school; $\mathrm{b}=$ secondary vocational school; $\mathrm{c}=$ secondary school) perceived these areas as problematic: remuneration (a-68.1\%; b-76.5\%; c-77.8\%); job satisfaction (a-62.3\%; b-64.7\%; c-61.1\%); students' behavior during classes (a-56.5\%; b-58.8\%; c-38.9\%); students' aggressiveness (a-60.9\%; b-47.1\%; c-55.6\%); students' performance (a-44.9\%; b-52.9\%; $\mathrm{c}-55.6 \%$ ). Other problem areas that have been mentioned in at least two types of schools included: stress linked to the teaching profession; work with a minority group; communication with parents; class size; working conditions; school's financial resources; teacher status in society and perceived value of teacher's work. Other areas didn't label as problematic. The research findings have extended the previous research in the context of Slovak teachers' turnover, which is little researched in Slovakia and is limited to the determining the current status of turnover without any deeper understanding of the causes. However, knowing the causes of Slovak teachers' turnover may be helpful in reducing it.
\end{abstract}

Keywords: Teacher turnover, factors, Slovak teachers.

\section{Introduction}

There is considerable tension among Slovak teachers today even though efforts are being made to improve their working conditions through various legislative amendments and teacher-related agreements. There are still a number of areas related to the teaching profession, teaching, and the education system as such that are problematic (Harkotová, 2018). It is important to note that not solving teachers' problems translates into turnover tendencies and turnover itself. Turnover is a voluntary departure from one's current job or organization (Milovanovic, 2017). Most studies focus on turnover tendencies as indicators of an intention to leave. Turnover tendencies or intentions to change one's job are defined as a deliberate and willingly controlled mental activity containing motivational elements, which leads the individual to leave the current organization (Tett \& Meyer, 1993). Turnover is defined as a final product and turnover tendencies as a precursor to actual turnover. Turnover is linked to a number of negative impacts, including negative financial impacts (Abbasi, Hollman, \& Hayes, 2008; Barnes, Crowe, $\&$ Schaefer, 2007); negative consequences on the remaining employees (Abbasi et al., 2008; Yin-Fah, Sok Foon, Chee-Leong, \& Osman, 2010); greater school instability, disruption of curricular cohesiveness, and a continual need to hire inexperienced teachers, who are typically less effective (Grissom, 2011). 
According the literature and research studies review, there are a lot of determinants or factors related turnover and turnover tendencies, and opinions on them vary from author to author. We include to these factors according the other autrhors: size of school (Barnes et al., 2007); type of school (Cano et al., 2017; Stuit \& Smith, 2010); working (organizational) conditions (Stuit \& Smith, 2010; Ingersoll, 2001b; Grant, Jeon, \& Buettner, 2019); class autonomy of the teachers (Ingersoll \& May, 2012); superiors, management (Ingersoll, 2001a; Grissom, 2011; Kraft, Marinell, \& Shen-Wei Yee, 2016); mentoring (Smith \& Ingersoll, 2004); school poverty (Allen, Burgess, \& Mayo, 2017; Barnes et al., 2007; Holme, Jabbar, Germain, \& Dinning, 2017); students' performance (Barnes et al., 2007; Holme et al., 2017; Guin, 2004; Ronfeldt, Loeb, \& Wyckoff, 2013); students' behavior (Ingersoll, 2001a); minority (Holme et al., 2017; Guin, 2004; Barnes et al., 2007; Ronfeldt et al., 2013); remuneration (Ingersoll \& May, 2012; Ingersoll, 2001a); job satisfaction (Ajayi \& Olatunji, 2018; Kravčáková et al., 2011; Addai et al., 2018); motivation (Grant et al., 2019); personal health (Ajayi \& Olatunji, 2018); subjective well-being (Yang, Fan, Chen, Hsu, \& Chien, 2018; Grant et al., 2019); role stress (Yang et al., 2018); teacher victimization (Curran, Viano, \& Fisher, 2017); Burn-out syndrome (Laschinger \& Fida, 2014; Huei-Ling \& Ven-hwei, 2017); conflict between professional life and personal life (Ajayi \& Olatunji, 2018; O'Neill et al., 2009); organizational justice (Addai et al., 2018); organizational commitment (Bull, 2005 in Ajayi \& Olatunji, 2018); job involvement (Ashrafi, Farzaneh, \& Azizi, 2017); freedom to decide (Ingersoll, 2001a); work engagement (Wan, Li, Zhou, \& Shang, 2018).

We can see that there are a lot of factors in play. We assume that turnover and turnover tendencies are closely linked to the situation in the country, economic conditions, job description specifics, etc. We conducted a survey to identify the most important factors relevant to Slovak teachers, focusing on the areas teachers consider to be particularly problematic, i.e. potential reasons for turnover tendencies or actual turnover.

\section{Goal of the survey}

The goal of the survey was to identify the most important factors determining Slovak teachers' turnover tendencies and actual turnover according the type of school, in which they teach (preschools, primary schools, secondary vocational schools, secondary schools).

\section{Methods}

\subsection{Study sample and procedure}

Our survey involved 132 teachers $(87.1 \%$ women), aged 24 to 68 (Mage $=38.03, \mathrm{SD}=10.20)$. Of the total number of teachers, $15.6 \%$ worked at preschools, $53.9 \%$ worked at primary schools, $13.3 \%$ worked at secondary vocational schools, $14.1 \%$ worked at secondary schools, and $3.1 \%$ worked at other types of schools.

The research sample was selected from teachers reachable via social networks or email, taking advantage of the snowball effect. Suitable research participants $(n=150)$ were subsequently contacted online. After giving their informed consent, they filled in an online survey questionnaire.

\subsection{Measures}

At the beginning, we looked into the following social-demographic variables:

- gender;

- age;

- the type of school the individual teaches in (preschool / primary / secondary vocational / secondary / other);

Subsequently, the teachers had a list of areas at their disposal, where they were able to choose a maximum of 7 areas they consider to be the most problematic in the teaching profession; more precisely, they were asked the following question: "What are you dissatisfied with and what type of departure would you consider for what area if this was possible?" The individual areas they could choose from were written down based on our review of the researched factors determining teacher turnover and turnover tendencies. The list included 27 areas related to the teaching profession. Additionally, the teachers involved in the survey were also given the choice of adding another area, other than those specified in the compiled list.

\subsection{Statistical analysis}

The information collected in the course of the survey was processed using descriptive statistics available in the SPSS 21.0 program. 


\section{Results}

The goal of this survey was to select the most important factors of Slovak teachers' turnover tendencies and turnover itself. Table 1 shows the percentage representation of individual researched areas depending on the areas the respondents consider the most problematic in the teaching profession, that is to say, areas that would make them consider any type of departure.

Table 1. A percentage representation of individual areas depending on perceived problems in the teaching profession according the type of school, in which teachers teach.

\begin{tabular}{|c|c|c|c|c|c|}
\hline Researched area & preschools & $\begin{array}{r}\text { type } \\
\text { primary } \\
\text { schools }\end{array}$ & $\begin{array}{l}\text { school } \\
\text { secondary } \\
\text { vocational } \\
\text { schools }\end{array}$ & $\begin{array}{l}\text { secondary } \\
\text { schools }\end{array}$ & TOTAL \\
\hline Remuneration & $90.0 \%$ & $68.1 \%$ & $76.5 \%$ & $77.8 \%$ & $72.7 \%$ \\
\hline Job satisfaction & $65.0 \%$ & $62.3 \%$ & $64.7 \%$ & $61.1 \%$ & $63.6 \%$ \\
\hline $\begin{array}{l}\text { Students' behavior during } \\
\text { classes }\end{array}$ & $20.0 \%$ & $56.5 \%$ & $58.8 \%$ & $38.9 \%$ & $50.0 \%$ \\
\hline $\begin{array}{l}\text { Stress linked to the teaching } \\
\text { profession }\end{array}$ & $30.0 \%$ & $58.0 \%$ & $52.9 \%$ & $27.8 \%$ & $47.0 \%$ \\
\hline Students' aggressiveness & $0.0 \%$ & $60.9 \%$ & $47.1 \%$ & $55.6 \%$ & $45.5 \%$ \\
\hline Work with a minority group & $30.0 \%$ & $50.7 \%$ & $47.1 \%$ & $16.7 \%$ & $42.4 \%$ \\
\hline Students' performance & $10.0 \%$ & $44.9 \%$ & $52.9 \%$ & $55.6 \%$ & $42.4 \%$ \\
\hline Communication with parents & $20.0 \%$ & $42.0 \%$ & $29.4 \%$ & $55.6 \%$ & $42.4 \%$ \\
\hline $\begin{array}{l}\text { Class size (number of } \\
\text { students in class) }\end{array}$ & $30.0 \%$ & $34.8 \%$ & $52.9 \%$ & $16.7 \%$ & $33.3 \%$ \\
\hline $\begin{array}{l}\text { Working conditions } \\
\text { (environment) }\end{array}$ & $30.0 \%$ & $34.8 \%$ & $35.3 \%$ & $16.7 \%$ & $33.3 \%$ \\
\hline School's financial resources & $30.0 \%$ & $23.2 \%$ & $35.3 \%$ & $44.4 \%$ & $28.8 \%$ \\
\hline Non-financial benefits & $20.0 \%$ & $21.7 \%$ & $41.2 \%$ & $22.2 \%$ & $22.7 \%$ \\
\hline $\begin{array}{l}\text { Management, superiors and } \\
\text { relationship to them }\end{array}$ & $50.0 \%$ & $11.6 \%$ & $5.9 \%$ & $5.6 \%$ & $16.7 \%$ \\
\hline $\begin{array}{l}\text { Teacher status and value of } \\
\text { teacher's work }\end{array}$ & $5.0 \%$ & $4.3 \%$ & $35.3 \%$ & $50.0 \%$ & $16.7 \%$ \\
\hline $\begin{array}{l}\text { Quality of relationships with } \\
\text { colleagues }\end{array}$ & $30.0 \%$ & $13.0 \%$ & $5.9 \%$ & $11.1 \%$ & $13.6 \%$ \\
\hline Health risks & $10.0 \%$ & $11.6 \%$ & $5.9 \%$ & $16.7 \%$ & $13.6 \%$ \\
\hline Perception of justice & $30.0 \%$ & $11.6 \%$ & $5.9 \%$ & $16.7 \%$ & $13.6 \%$ \\
\hline $\begin{array}{l}\text { Career growth, opportunities } \\
\text { for promotion }\end{array}$ & $10.0 \%$ & $13.0 \%$ & $5.9 \%$ & $11.1 \%$ & $12.1 \%$ \\
\hline $\begin{array}{l}\text { Work with students in } \\
\text { general }\end{array}$ & $0.0 \%$ & $14.5 \%$ & $5.9 \%$ & $16.7 \%$ & $12.1 \%$ \\
\hline Support from superiors & $30.0 \%$ & $4.3 \%$ & $5.9 \%$ & $22.2 \%$ & $12.1 \%$ \\
\hline Motivation & $10.0 \%$ & $7.2 \%$ & $23.5 \%$ & $5.6 \%$ & $9.1 \%$ \\
\hline $\begin{array}{l}\text { Work commitment and } \\
\text { engagement }\end{array}$ & $10.0 \%$ & $8.7 \%$ & $5.9 \%$ & $11.1 \%$ & $9.1 \%$ \\
\hline Workplace communication & $10.0 \%$ & $5.8 \%$ & $5.9 \%$ & $16.7 \%$ & $7.6 \%$ \\
\hline Mobbing / bossing & $20.0 \%$ & $2.9 \%$ & $0.0 \%$ & $11.1 \%$ & $6.1 \%$ \\
\hline Type of job (work itself) & $10.0 \%$ & $5.8 \%$ & $0.0 \%$ & $0.0 \%$ & $4.5 \%$ \\
\hline $\begin{array}{l}\text { Conflict between } \\
\text { professional life and } \\
\text { personal life }\end{array}$ & $0.0 \%$ & $4.3 \%$ & $5.9 \%$ & $0.0 \%$ & $3.0 \%$ \\
\hline $\begin{array}{l}\text { Freedom to take decisions } \\
\text { and manage }\end{array}$ & $0.0 \%$ & $2.9 \%$ & $5.9 \%$ & $5.6 \%$ & $3.0 \%$ \\
\hline
\end{tabular}

In relation to the presented results, we will focus on areas (factors) identified as problematic in the teaching profession by at least one third of the respondents. 


\section{Discussion and conclusion}

We can conclude that more attention is paid to teacher turnover tendencies and teacher turnover abroad than in Slovakia. In the course of our study, a number of background factors were researched, too. In Slovakia, research is focused more on determining the current status of turnover and turnover tendencies without any deeper understanding of the causes; alternatively, turnover and turnover tendencies are only seen through problematic areas. Little attention is paid to the reasons causing the turnover of teachers, which leads to the fact that no effective effort is made to solve the turnover of Slovak teachers. It seems to be generally agreed that remuneration and issues encountered by teachers are the main reasons for turnover. However, there is no focus on what could motivate Slovak teachers to remain in their profession, finding ways of helping them solve their problems, or convincing them that their work is important and appreciated.

We assume that if we want to solve teachers' turnover tendencies and actual turnover, we have to take a closer look at what lies beneath, i.e. the factors that determine the phenomena in question. However, based on our review of existing research, we conclude that there are an almost infinite number of factors determining teachers' turnover tendencies and turnover itself, which is why we need to select only those that are relevant to Slovak teachers. We were able to do this after a thorough analysis of all the factors and additional information specified by Slovak teachers in surveys recently conducted in Slovakia. The result was a list of 27 areas, which we subsequently submitted to a sample of Slovak teachers, asking them to indicate which of the 27 areas they consider the most problematic and which of them would prompt them to consider any type of departure. We focused on areas that had been marked as problematic by at least one third of the Slovak teachers in the research sample, namely remuneration, job satisfaction; students' behavior during classes, aggressiveness, and performance; stress linked to the teaching profession; work with a minority group; communication with parents; class size; and working conditions (environment).

This research represents the first step in searching the causes of turnover tendencies and turnover of teachers and is the basic for our future researches, which will be focused on choosing factors in wider context. The aim will be reduction of turnover tendencies and turnover through motivate Slovak teachers to remain in their profession through the focusing on improving the job satisfaction or learning how to manage teacher stress or how better communicate with parents etc. we will focus mainly on these areas, which were revealed as problematic in our research.

\section{References}

Abbasi, S. M., Hollman, K. W., \& Hayes, R. D. (2008). Bad Bosses and How Not to Be One. Information Management Journal, 42(1), 52-56. Retrieved August 15, 2019, from: http://www.calgarypsychologygroup.com/PDF/bad\%20bosses\%20and\%20how\%20not\%20to\%20 be\%20one.pdf

Addai, P., Kyeremeh, E., Abdulai, W., \& Sarfo, J. O. (2018). Influence of Organizational Justice and Job satisfaction on turnover Intentions among Teachers. European Journal of Contemporary Education, 7, 235-243.

Ajayi, S. O., \& Olatunji, A. O. (2018). Turnover Causation Amongst High School Teachers in Nigeria. Africa Education Review, 16(2), 1-15.

Allen, R., Burgess, S., \& Mayo, J. (2017). The teacher labour market, teacher turnover and disadvantaged schools: new evidence for England. Education Economics, 26(1), 1-20.

Ashrafi, S., Farzaneh, M., \& Azizi, M. (2017). Investigating the Relationship of Talent Management and Teachers Turnover Intentions with the Mediating Effect of Job Involvement. New Thoughts on Education, 13(1), 137-162.

Barnes, G., Crowe, E., \& Schaefer, B. (2007). The cost of teacher turnover in five school districts: A pilot study. Washington, DC: National Commission on Teaching and America's Future.

Cano, S. L., Flores, B. B., Claeys, L., \& Sass, D. A. (2017). Consequences of Educator Stress on Turnover: The Case of Charter Schools. In T. M. McIntyre, S. E. McIntyre, D. J. Francis (Eds.), Educator Stress: An Occupational Health Perspective (pp. 127-155). Cham: Springer.

Curran, F. Ch., Viano, S. L., \& Fischer, B. W. (2017). Teacher victimization, turnover, and contextual factors promoting resilience. Journal of School Violence, 18(3), 21-38.

Grant, A. A., Jeon, L., \& Buettner, C. K. (2019). Relating early childhood teachers' working conditions and well-being to their turnover intentions. Educational Psychology, 39, 294-312. 
Grissom, J. A. (2011). Can Good Principals Keep Teachers in Disadvantaged Schools? Linking Principal Effectiveness to Teacher Satisfaction and Turnover in Hard-to-Staff Environments. Teachers College Record, 113, 2552-2585.

Guin, K. (2004). Chronic Teacher Turnover in Urban Elementary Schools. Education Policy analysis archives, 12(42), 1-30.

Harkotová, S. (2018, June 15). Protest učitel'ov: Ministerstvo školstva je ministerstvom nat'ahovania času [Teacher protest: The Ministry of Education is the Department of Time Stretching]. Retrieved August 25, 2019, from https://www.aktuality.sk/clanok/599640/protest-ucitelov-ministerstvoskolstva-je-ministerstvom-natahovania-casu/

Holme, J. J., Jabbar, H., Germain, E., \& Dinning, J. (2017). Rethinking Teacher Turnover in Texas: Longitudinal Measures of Instability in Schools. POLICY BRIEF: Education Research Center, The University of Texas at Austin.

Huei-Ling L., \& Ven-Hwei L. (2017). An Integrated Model of Workload, Autonomy, Burnout, Job Satisfaction, and Turnover Intention among Taiwanese Reporters, Asian. Journal of Communication, 28, 153-169.

Ingersoll, R. M. (2001a). Teacher Turnover, Teacher Shortages, and the Organization of Schools. CPRE Research Reports. Retrieved June 21, 2019, from https://repository.upenn.edu/cpre_researchreports/12

Ingersoll, R. M. (2001b). Teacher Turnover and Teacher Shortages: An Organizational Analysis. American Educational Research Journal, 38, 499-534.

Ingersoll, R. M., \& May, H. (2012). The Magnitude, Destinations, and Determinants of Mathematics and Science Teacher Turnover. Educational Evaluation and Policy Analysis, 34(4), 435-464.

Kraft, M., Marinell, W. H., \& Shen-Wei Yee, D. (2016). School Organizational Contexts, Teacher Turnover, and Student Achievement. American Educational Research Journal, 53, 1411-1449.

Kravčáková, G., Lukáčová, J., \& Búgelová, T. (2011). Práca a kariéra vyokoškolského učitel’a [Work and career of a university teacher]. Košice: Univerzita Pavla Jozefa Šafárika v Košiciach.

Laschinger, H. K. S., \& Fida, R. (2014). A Time-Lagged Analysis of the Effect of Authentic Leadership on Workplace Bullying, Burnout, and Occupational Turnover Intentions. European Journal of Work and Organizational Psychology, 23, 739-753.

Milovanovic, I. (2017). Big-Five Personality Traits, Job Satisfaction, and Turnover Intention: A Heuristic Model for Hospital Nurses in Japan. International Journal of Scientific \& Engineering Research, $8,267-275$.

O’Neill, J. W., Harrison, M. M., Cleveland, J., Almeida, D., Stawski, R., \& Crouter, A. C. (2009). Work-family Climate, Organizational Commitment, and Turnover: Multilevel Contagion Effects of Leaders. Journal of Vocational Behavior, 74(1), 18-29.

Ronfeldt, M., Loeb, S., \& Wyckoff, J. (2013). How Teacher Turnover Harms Student Achievement. American Educational Research Journal, 50(1), 4-36.

Smith, T. M., \& Ingersoll, R. M. (2004). What Are the Effects of Induction and Mentoring on Beginning Teacher Turnover? American Educational Research Journal, 41(3), 681-714.

Stuit, D., \& Smith, T. M. (2010). Teacher Turnover in Charter Schools. Nashville: National Center on School Choice. Retrieved September 10, 2019, from https://www.researchgate.net/profile/Thomas_Smith26/publication/255600494_Teacher_Turnover in_Charter_Schools/links/0c960537cf9c4b270c000000/Teacher-Turnover-in-Charter-Schools.pdf

Tett, R. P., \& Meyer, J. P. (1993). Job Satisfaction, Organizational Commitment, Turnover Intention, and Turnover: Path Analyses Based On Meta-Analytic Findings. Personnel Psychology, 46, 259-293.

Wan, Q., Li, Z., Zhou, W., \& Shang, S. (2018). Effects of Work Environment and Job Characteristics on the Turnover Intention of Experienced Nurses: The mediating role of Work Engagement. Journal of Advanced Nursing, 74, 1332-1341.

Yang, Ch. Ch., Fan, Ch. W., Chen, K. M., Hsu S. Ch., \& Chien, Ch. L. (2018). As a Happy kindergarten Teacher: The Mediating Effect of Happiness Between Role Stress and Turnover Intention. The Asia-Pacific Education Researcher, 27, 431-440.

Yin-Fah, B., Sok Foon, Y., Chee-Leong, L., \& Osman, S. (2010). An Exploratory Study on Turnover Intention among Private Sector Employees. International Journal of Business and Management, $5(8), 57-64$. 